\title{
Dangers hang over dependency
}

\section{Peter Francis}

MonTSERRAT is erupting. Starting in late July, the Soufriere Hills volcano which dominates the southern part of the island has become considerably more active. Sustained periods of low-frequency, highamplitude tremor have been recorded by seismographs, implying the intrusion of new magma, three to five kilometres beneath the summit. They also cause continuous rock falls lasting for several hours, such as the one that produced the dense curtain of ash shown here (Fig. 1).

Occasionally much larger 'pyroclastic flows' of hot rock and gases have been produced. Several of them have travelled along the valley of the Tar River as far as the sea, building a new delta that extends 400 metres into the sea. Dust clouds rise convectively from the pyroclastic flows and reach an altitude of about 10 kilometres, triggering displays of thunder and lightning, and presenting a hazard to aircraft using the many routes that crisscross the Caribbean.

The reawakening of the Soufrière Hills volcano last year after 400 years of inactivity precipitated a crisis for this small British Dependent Territory. Thousands of people have been moved from the southern part of the island, including the capital town of Plymouth, only four kilometres from the crater.

Since September 1995, the volcanic activity on Montserrat has been domi-

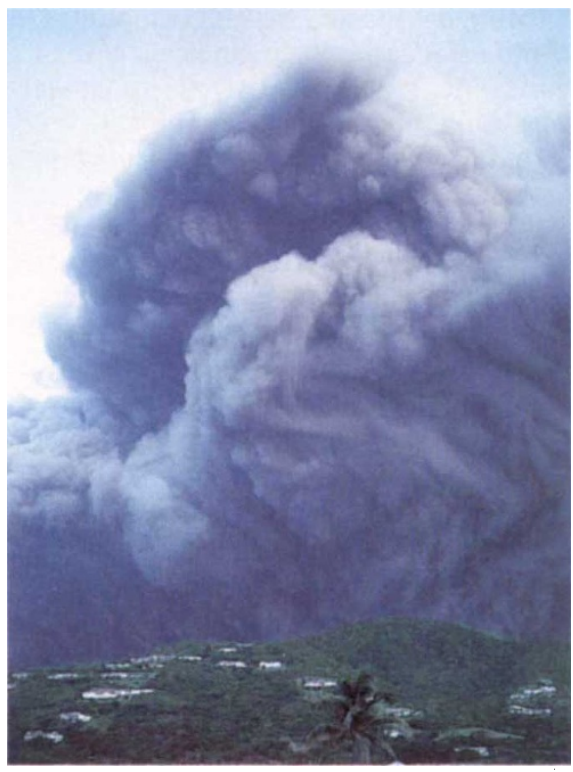

FIG. 1 Dust clouds, drifting many kilometres downwind of the rock falls that produced them. nated by extrusions of andesitic lava into the summit crater at a rate of about $100,000 \mathrm{~m}^{3}$ per day, forming a new dome complex. This is a unique opportunity for many scientists (from the University of the West Indies and from Britain) to study the evolution of a lava dome at close quarters using a wide range of geophysical and

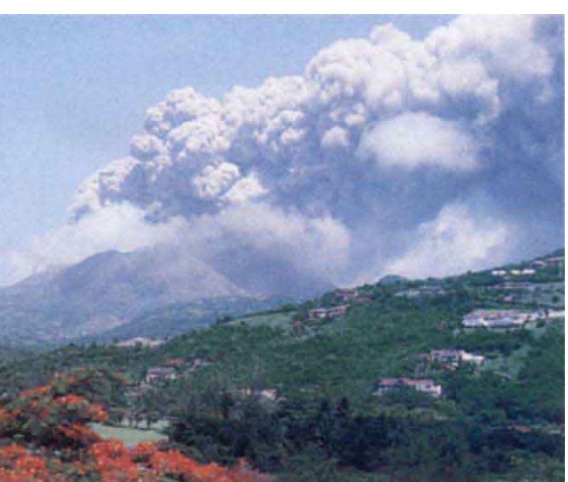

FIG. 2 Convective ash columns above the volcano on 29 July. Although resembling an explosive eruption column, there was no true explosive activity, and no open vent. The ash column was made of dust from rocks pulverized in avalanches. problem, for both scientific and practical reasons, is why the magma is depleted in volatiles, with a low ratio of $\mathrm{SO}_{2}$ to $\mathrm{HCl}$. It is the volatile content of magmas that powers dangerously explosive eruptions.

Intermittently, the dome becomes so steep that portions break away to become avalanches of hot rocks, variously termed glowing avalanches, nuées ardentes or pyroclastic flows. These avalanches in turn generate tall, convective ash clouds (Fig. 2). This sort of activity is well known as a volcanic hazard in the West Indies, having first been seen on the neighbouring island of Martinique during the catastrophic 1902-1905 eruption of Mt. Pelée which destroyed the town of St Pierre.

Ever since the dome began to grow, the concern has been that it might eventually overtop the western rim of the existing crater wall, allowing pyroclastic flows to descend towards Plymouth. Although part of the dome did rise above the wall on that side, the most recent activity has been concentrated on the north-east side of the dome, so recent pyroclastic flows have all followed the path of earlier flows down the Tar River. But the message from Mt. Pelée and elsewhere is that eruptions of this sort can continue for months or even years, and parts of southern Montserrat could be under threat for a long time.

Peter Francis is in the Department of Earth Sciences, The Open University, Walton Hall, Milton Keynes MK7 6AA, UK.

\section{Surprising damp}

BUILDERS and householders, especially in rain-soaked Britain, are terrified of rising damp. A wall of porous bricks based in wet soil is soon saturated with water, which rises through the capillary network of its pores. It softens plaster, peels paint and rots woodwork attached to the wall. One answer is the electro-osmotic dampproof course. This keeps the wall a volt or so positive with respect to the ground. The potential difference generates an electro-osmotic pressure in the pores of the brickwork, which opposes upward capillary flow. But installing the system requires some care. If it is accidentally given the reverse polarity, it will suck the damp upwards with extra force.

In this connection, Daedalus notes that plants depend entirely on rising damp. They take in water through their roots, pump it up through their stems and branches, and expel it as vapour from their leaves. In clean and well soaked soil, they flourish mightily. But in salty soil, they have problems.

To extract water from salt solution, the roots of the plant have to suck against an osmotic pressure of maybe many atmospheres. They have to generate an even greater extractive osmotic pressure of their own, taxing the metabolic resources of the plant.

So Daedalus is devising a reversepolarity electro-osmotic pumping system for plants, to help their damp to rise. The smaller the pores in such a system, the greater the resulting pressure. Daedalus estimates that across the nanometresized pores of a semi-permeable root membrane, a few tens of volts could generate many hundreds of atmospheres of extractive osmotic pressure. DREADCO biophysicists are now tying electrodes around the stems of various vegetables, bushes and trees, and burying counterelectrodes in the soil nearby. With the right strength and polarity of applied voltage, the plants should grow with accelerated vigour even in salty or contaminated soil. When the system has been perfected, DREADCO will sell it to the world's farmers.

At last the creeping pollution of the world's water tables and irrigation systems will no longer matter. Aided by electric power, crops will flourish in industrial effluent, salt marshes, maybe even in the sea itself. With a high enough voltage, a plant might even extract water from the humidity of the air. It would then become a sort of electrically powered living dehumidifier, condensing water from the air onto its roots, evaporating it back from its leaves, and needing no water or soil at all. The industrialization of agriculture would be complete. 